\title{
THE MARINE BIOLOGICAL ASSOCIATION OF THE UNITED KINGDOM
}

ThE Association was founded in 1884 to promote accurate researches leading to the advancement of zoological and botanical science and to an increase in our knowledge of the food, life, conditions and habits of British fishes. The work of the Association is controlled by a Council elected annually by its subscribing members.

Professor T. H. Huxley took the chair at the initial meeting held in the rooms of the Royal Society and was elected the first President. Among those present were Sir John Lubbock (afterwards Lord Avebury), Sir Joseph Hooker, Professor H. N. Moseley, Mr G. J. Romanes, and Sir E. Ray Lankester who, after Professor Huxley, was for many years president of the Association. It was decided to build a laboratory at Plymouth, where a rich and varied fauna is found.

The Plymouth Laboratory was opened in June 1888, and, since that date, considerable additions have been made to the buildings, including a library, lecture-hall, and extensive laboratory accommodation with up-to-date equipment. Additional sea-water reservoirs have also been built, and an aquarium, modernized in 1959, opened to the public.

Since its foundation the Association has been supported by subscriptions and donations from private members, universities, learned societies, the Fishmongers' Company and other public bodies. For some time past, however, the main financial support for the work of the Plymouth Laboratory has come from Government funds, and since 1965 the Laboratory has been grant-aided through the Natural Environment Research Council.

The Marine Biological Association, under the direction of its Council, undertakes research in all branches of marine science and the main results are published in this journal. Accounts of the laboratory and aquarium are to be found in Vol. 27 (p. 761), Vol. 39 (p. 391) and Vol. 43 (p. 281), and summaries of the activities and research of the Association are given annually in the Report of the Council in the November issue of the Journal.

The laboratory is open throughout the year and its work is carried out by a fully qualified research staff under the supervision of the Director. The names of the members of the staff will be found on the inner page of the front cover. Accommodation is available for British and foreign scientific workers who wish to carry out independent research in all branches of marine science. Arrangements are made for courses for advanced students, and marine animals and plants are supplied to educational institutions.

Work at sea is undertaken by three research vessels and by a motor boat, and these also collect the specimens required in the laboratory.

\section{TERMS OF MEMBERSHIP}

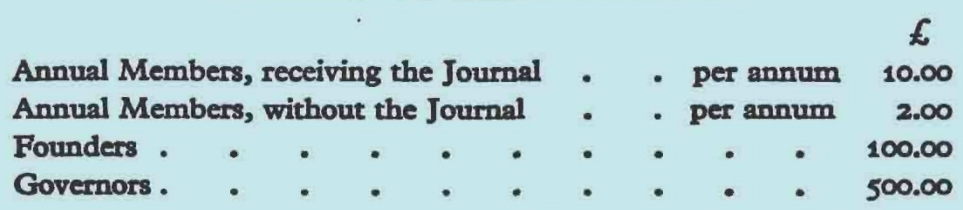

Members of the Association have the following rights and privileges: they elect annually the Officers and Council; they are entitled to receive the Journal of the Association at a reduced rate; they are admitted to view the laboratory at Plymouth; they have the first claim to rent a place in the laboratory for research, with use of tanks, boats, etc; they have the privilege of occupying a table for one week in each year free of charge; and they have access to the books in the library at Plymouth during working hours.

The Commissioners of Inland Revenue have approved the Association for the purposes of Section 16, Finance Act, 1958, and that the whole of the annual subscription paid by a member who qualifies for relief under the section will be allowable as a deduction from his emoluments assessable to income tax under Schedule $\mathbf{E}$.

All correspondence should be addressed to the Director, The Laboratory, Citadel Hill, Plymouth, PL1 2PB. 


\section{CONTENTS}

PARKE, M. and LeadBeater, B. S. C. Check-list of British marine Choanoflagellida - second revision

GreEn, J. C. and PienaAr, R. N. The taxonomy of the order Isochrysidales (Prymnesiophyceae) with special reference to the genera Isochrysis Parke, Dicrateria Parke and Imantonia Reynolds

Cox, E. J. The distribution of tube-dwelling diatom species in the Severn Estuary . .

BonLCH, G. T. and PotTs, G. W. The first occurrence of Sargassum muticum (Yendo) Fensholt in the Plymouth area

NorToN, T. A. Ecological experiments with Sargassum muticum $\quad . \quad$. . . .

HIBBERD, D. J. Observations on the ultrastructure of the cryptomonad endosymbiont of the red-water ciliate Mesodinium rubrum

DAVENPORT, J. A study of the effects of copper applied continuously and discontinuously to specimens of Mytilus edulis (L.) exposed to steady and fluctuating salinity levels .

BRYAN, G. W. and Hummerstone, L. G. Indicators of heavy-metal contamination in the Looe Estuary (Cornwall) with particular regard to silver and lead . . . .

EMsoN, R. H. The feeding and consequent role of Eulalia viridis (O. F. Müller) (Polychaeta) in intertidal communities

Freeman, R. F. H. and SHUtTlewORTH, T. J. Distribution of dry matter between the tissues and coelom in Arenicola marina (L.) equilibrated to diluted sea water . .

GrBBs, P. E. On the status of Golfingia intermedia (Sipuncula). . . . . .

HopkINS, C. C. E. and MACHIN, D. Patterns of spermatophore distribution and placement in Euchaeta norvegica (Copepoda: Calanoida)

OLIVE, P. J. W. The life-history and population structure of the polychaetes Nephtys caeca and Nephtys hombergii with special reference to the growth rings in the teeth .

WARREN, L. M. The ecology of Capitella capitata in British waters .
NEWELL, R. C. and KofoED, L. H. The energetics of suspension-feeding in the gastropod Crepidula fornicata L. .

Morris, R. J., Armitage, M. E., Raymont, J. E. G., Ferguson, C. F. and Raymont, J. K. B. Effects of a starch diet on the lipid chemistry of Neomysis integer (Leach) . .

Moore, P. F. Additions to the littoral fauna of Rockall, with a description of Araeolaimus penelope sp.nov. (Nematoda: Axonolaimidae)

KrEss, A. Runcina ferruginea n.sp. (Cephalaspidea: Opisthobranchia: Gastropoda), a new runcinid from Great Britain

Fish, J. D. and FisH, S. The effects of temperature and salinity on the embryonic development of Hydrobia ulvae (Pennant)

DALY, J. M. and GoldING, D. W. A description of the spermatheca of Spirorbis spirorbis (L.) (Polychaeta: Serpulidae) and evidence for a novel mode of sperm transmission . .

AL-ADHUB, A. H. Y. and BowERs, A. B. Growth and breeding of Dichelopandalus bonnieri in Isle of Man waters.

ANGEL, M. V. Studies on Atlantic halocyprid ostracods: vertical distributions of the species in the top $1000 \mathrm{~m}$ in the vicinity of $44^{\circ} \mathrm{N}, 13^{\circ} \mathrm{W}$

BONE, Q. Mauthner neurons in elasmobranchs

KRYVI, H. and ToTLAND, G. K. Histochemical studies with microphotometric determinations of the lateral muscles in the sharks Etmopterus spinax and Galeus melastomus.

TAYLOR, A. C. and NAYLOR, E. Entrainment of the locomotor rhythm of Carcinus by cycles of salinity change

ABSTRACTS OF MEMOIRS

BOok Notices

(C) Copyright by the Marine Biological Association of the U.K. 1977

The subscription price of volume 57, 1977 of the Journal to non-members of the Association is $£ 45.00$ net a volume of four parts, post free, or US $\$ 105.00$ in U.S.A. and Canada, payable in advance. Single parts cost $£ 13.00$ (US $\$ 30.00$ in U.S.A. and Canada) plus postage. Subscriptions may be sent to any bookseller or to the London or New York office of Cambridge University Press.

\section{CAMBRIDGE UNIVERSITY PRESS}

BENTLEY HOUSE, 200 EUSTON ROAD, LONDON NW1 2DB

32 EAST 57 TH STREET, NEW YORK, N.Y. 10022

Printed in Great Britain at the University Press, Cambridge 